\title{
IDIOPATHIC HYPERCALCURIA IN A CHILD
}

\author{
BY \\ L. J. BEILIN* and BARBARA E. CLAYTON \\ From The Hospital for Sick Children, Great Ormond Street, London
}

(RECEIVED FOR PUBLICATION JANUARY 28, 1964)

Hypercalcuria occurs in many conditions including hyperparathyroidism, vitamin D poisoning, sarcoid, and renal tubular acidosis. In adult patients with renal calculi, the urinary calcium excretion may be high for no apparent reason. Such patients include (a) those described by Hodgkinson and Pyrah (1958), hypercalcuria being the only abnormal finding, and (b) those described by Henneman, Benedict, Forbes, and Dudley (1958): in this group the patients, who were all males, had a low serum phosphorus without hypercalcaemia in addition to hypercalcuria. Hodgkinson and Pyrah (1958) showed that hypercalcuria was associated with an increased incidence of stone formation, and demonstrated that hypercalcuria and the incidence of renal calculi were higher in men than in women. Four dwarfed children with hypercalcuria have recently been described by Royer (1962).

The present report describes a 6-year-old white English boy (E.B.) who had nephrocalcinosis. He was found to have hypercalcuria of the "idiopathic" variety as determined by systematic exclusion of disorders known to cause hypercalcuria. Hypercalcuria was also demonstrated in his father and brother but not in his mother.

Henneman, Dempsey, Carroll, and Albright (1956) suggested that sodium phytate might be of use in the treatment of hypercalcuria, since it was known that $2 \cdot 905$ g. of sodium phytate $\left(\mathrm{Na}_{12} \mathrm{C}_{6} \mathrm{H}_{6} \mathrm{O}_{24} \mathrm{P}_{6} \cdot 38 \mathrm{H}_{2} \mathrm{O}\right)$ would precipitate $0.306 \mathrm{~g}$. calcium (Hoff-Jørgensen, 1946; Hoff-Jørgensen, Andersen, and Nielsen, 1946). The treatment was used successfully by Henneman $e t$ al. (1958), who found that in combination with a high fluid intake and removal of cheese and milk from the diet, sodium phytate decreased the hypercalcuria and prevented the growth of renal stones and their recurrence. Hoff-Jørgensen et al. (1946) had already shown that the administration of sodium phytate to children led to a reduction in the absorption and retention of calcium, though changes in the urine were not very striking or consistent. It

- Present address: Department of Medicine, King's College Hospital Medical School, Denmark Hill, London, S.E.5. was pointed out by Nicolaysen, Eeg-Larsen, and Malm (1953) that the effect of phytic acid was only striking when calcium absorption was excessively high.

Since a low-calcium diet is unpalatable it was decided that an attempt should be made to treat E.B. with sodium phytate.

\section{Case History}

E.B. was born by breech delivery following a normal pregnancy. He weighed $3 \mathrm{lb}$. (1360 g.) at birth, although he was full-term by his mother's estimate. Neonatal development was normal but from 6 months to 1 year he vomited every two to three weeks for no obvious cause and without diarrhoea or obvious pain. He was fed on half-cream Cow \& Gate milk for the first five months and then on full-cream Cow \& Gate milk, until he was completely weaned several months later. Inguinal herniotomies were performed at 2 and 3 years of age; otherwise he was well until 5 years and 8 months when he complained of attacks of epigastric pain. These occurred every one to two months for eight months and lasted ten minutes only, during which time he appeared cold and pale. The pain was unrelated to food, micturition, or defaecation, and there was no vomiting. Since his energy diminished between attacks, he was sent to Ipswich Hospital in August 1961 (then aged 6 years and 4 months). A straight radiograph of the abdomen at Ipswich revealed fine diffuse generalized nephrocalcinosis, and he was referred to Sir Wilfrid Sheldon at Great Ormond Street for further investigation. At no time had he had vitamin supplements in any form.

On examination he was puny and had a high arched palate. Height $(106 \mathrm{~cm}$.) and weight $(16 \mathrm{~kg}$.) were both below the third percentile. There was no skeletal abnormality, no abdominal tenderness or masses, and no corneal or tympanic membrane calcification. Heart, lungs, and nervous system were normal. Blood pressure was $110 / 80 \mathrm{~mm}$. Hg. Skull diameter was $201 \mathrm{in}$. $(51 \mathrm{~cm}$.).

Family History. Both parents were alive and worked and lived on a farm in Suffolk. They were both $5 \mathrm{ft} .3$ in. $(160 \mathrm{~cm}$.) tall. The father had a mild symptomless hypertension $(160 / 100 \mathrm{~mm} . \mathrm{Hg})$. A brother of 10 years and a sister of 16 months were well. A grandmother who visited the family had pulmonary tuberculosis when E.B. was 4 years old. 
TABLE 1

TESTS TO EXCLLDE INFLAMMATORY DISEASE

\begin{tabular}{|c|c|}
\hline Tests & Results \\
\hline Microscopy of urine & Amorphous phosphates only \\
\hline Cell excretion rate per hour & $\begin{array}{l}\text { Red blood cells: } 30.000-285.000 \\
\text { White blood cells: } 18.000-95,000 \\
\text { Casts: } 12,000-38.000\end{array}$ \\
\hline $\begin{array}{c}\text { Cultures of early morning } \\
\text { urines }\end{array}$ & $\begin{array}{l}\text { A few colonies of coagulase- } \\
\text { negative staphylococci; no tubercle } \\
\text { bacilli demonstrated by culture or } \\
\text { inoculation of guinea-pigs }\end{array}$ \\
\hline White blood count & $4,800 \mathrm{~cm}$. with $52 \%$ neutrophils \\
\hline Haemoglobin & $11.5 \mathrm{~g} .100 \mathrm{ml}$ \\
\hline
\end{tabular}

\section{Investigations and Results}

The following $x$-ray examinations were made.

Intravenous pyelogram revealed fine diffuse calcification involving both renal cortex and medulla. The renal outlines and calyces were normal. The skull was normal and the lamina dura intact. The hands had normal bone density. The wrists showed that the bone age was consistent with a chronological age of 6 years and 5 months. The chest radiograph revealed a bifid seventh rib.

No evidence of metabolic disease involving the skeleton was observed.

Evidence of local inflammatory disease, past or present, e.g. chronic pyelonephritis or tuberculosis, was sought, and the investigations performed are shown in Table 1. The urinary white cell excretion rate was normal, but no attempt was made to stimulate this with pyrogen or prednisone. Though no evidence of acute or chronic

TABLE 2

BIOCHEMICAL INVESTIGATIONS

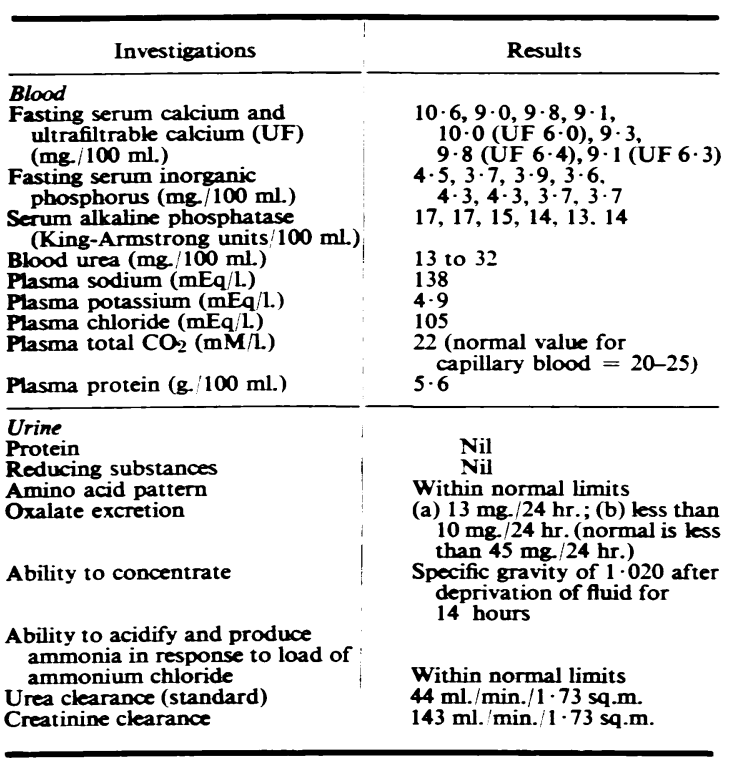

renal infection was revealed, chronic pyelonephritis cannot be excluded.

Biochemical investigation of the renal system (Table 2) gave results within normal limits, and the plasma bicarbonate was normal. Renal tubular acidosis, tubular defects of the Fanconi type, and primary hyperoxaluria were all excluded.

An initial five-day calcium balance (balance study I) as described by Clayton and Cotton (1961) showed definite hypercalcuria (Fig. 1 and Table 3). The mean daily urinary excretion of calcium was $232 \mathrm{mg}$.; Macy (1942)

TABLE 3

INITIAL 5-DAY CALCIUM AND PHOSPHORUS BALANCES (BALANCE I)

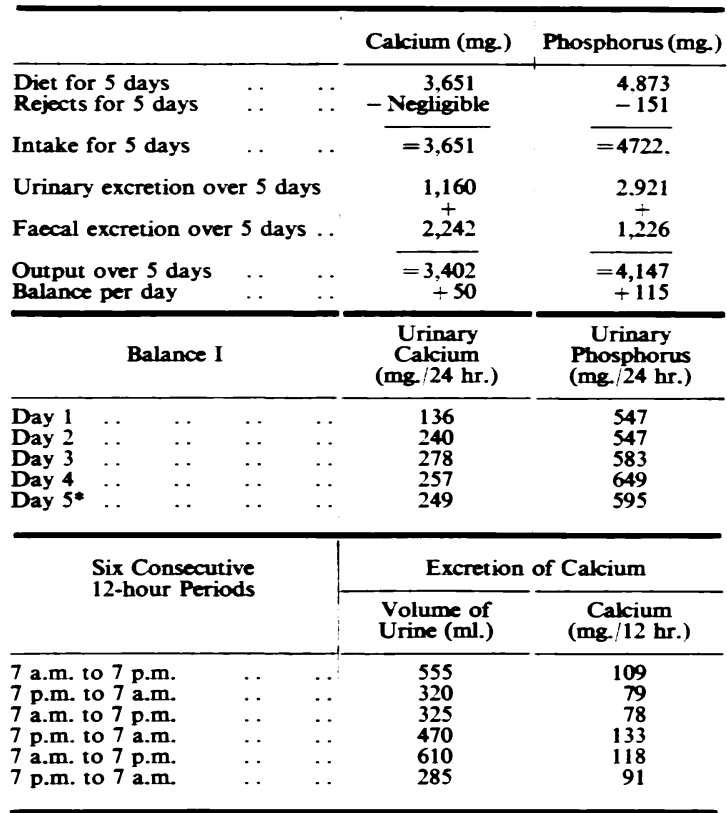

* One specimen lost during this 24-hour collection.

found an average excretion of $73=24 \mathrm{mg} . / 24$ hours for normal 6-year-old children, and Knapp (1947) gave a figure of $79 \doteq 39 \mathrm{mg}$. for normal 5- to 9-year-old children receiving 0.7 to $0.999 \mathrm{~g}$. calcium per day. There was no consistent diurnal variation in the excretion of calcium in urine produced during six consecutive 12-hour periods (Table 3). Only $6 \%$ of the calcium intake was actually retained; Macy (1942) gave a figure of $19 \%$ for normal 6-year-old children. The phosphorus balance was within normal limits, the percentage retained being $12 \%$ (normal value $=13 \%$ (Macy, 1942)).

Biochemical estimations on blood were performed on capillary samples obtained by the finger-prick method. Estimations were performed by micro-methods as described by Wilkinson (1960). Calcium was estimated by the method of Wilkinson (1957), the normal range being 8.5 to $10.7 \mathrm{mg} . / 100 \mathrm{ml}$. serum. Results are given in Table 2. Repeated fasting serum calcium levels were 

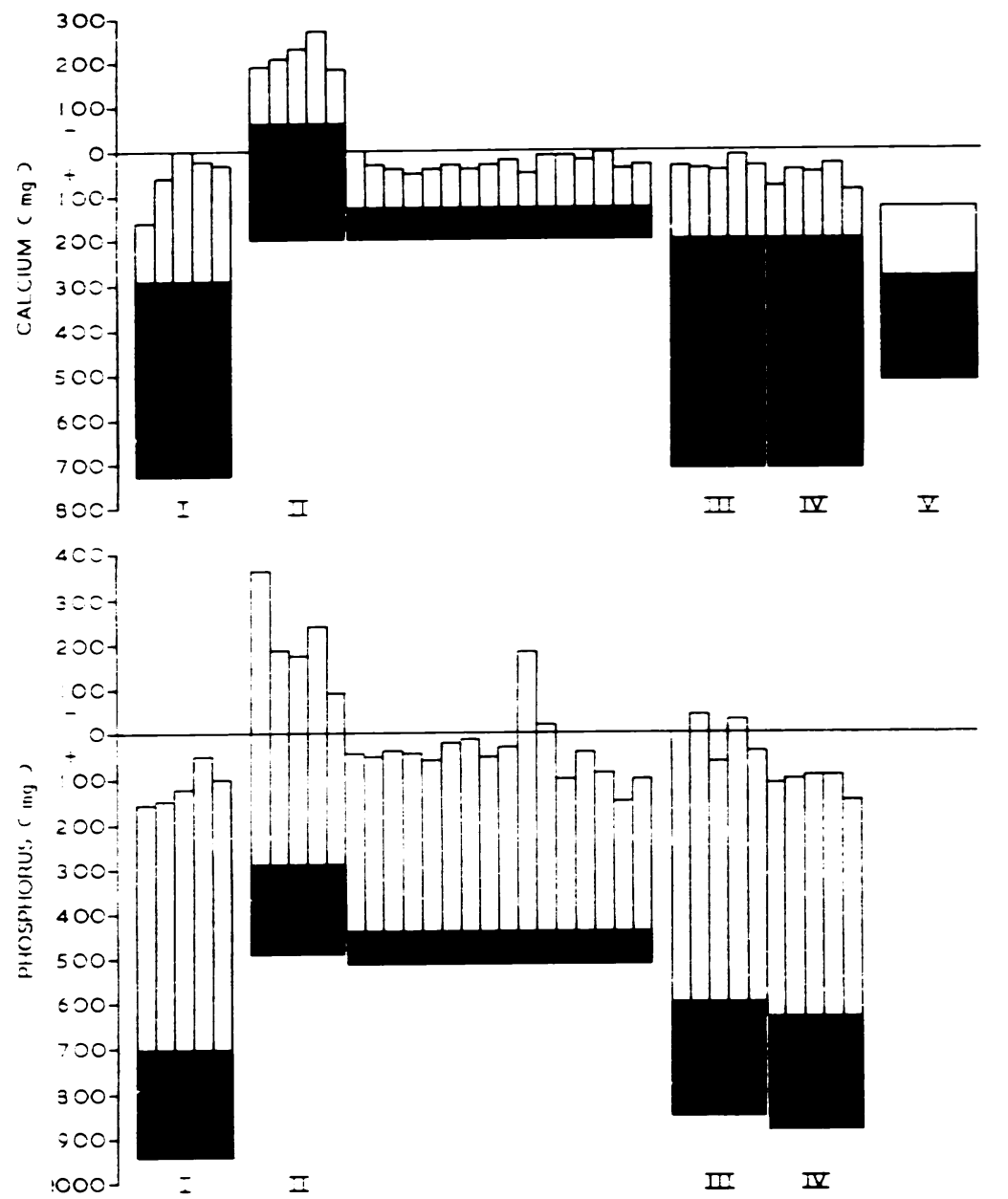

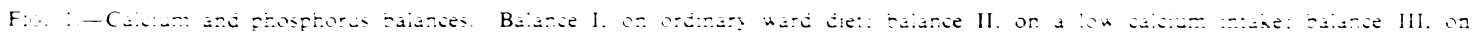

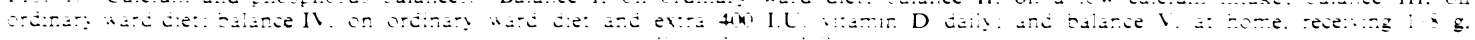

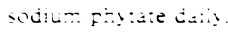

within the normal range and the ultrafiltrable calcium was also within normal limits. The mean serum phosphorus of $4.0 \mathrm{mg} .100 \mathrm{ml}$. was at the lower end of the normal range 13.8 to $\$ 2 \mathrm{mg} .100 \mathrm{ml} .1$ for t-year-old shildren.

During balance study. II the patient was placed on a low calcium diet. and on this regime he intially went into negative halance (Fig. 11. He then went into fositive balance and his daily urinary excretion of calcium fell significantly. These results. together with the negative radiological findings. were strongly against hyperparathyroidism as a cause of the hypercalcuria.

During balance study IV (Fig. 1 , he was given an extra 400 units of vitamin D daily for five consecutive dass and the results were compared with those of balance study III IFig. 11. when he was receiving no extra vitamin $D$ but a normal diet. No increase in calcium absorption observed and increased sensitivity to dietary vitamin D seemed unlikely to be responsible for the hipercalcuria. He had never been exposed to excess vitamin D.

It was. therefore. concluded that the child had hypercalcuria with nephrocalcinosis for which no cause could be found.

Since idiopathic hypercalcuila mas the a familial disorder. 24-hour urine specimens from both parents and a 10-year-old brother were examined (Table 4). Both father and brother had raised urinary calcium levels with normal serum calciums and normal blood ureas. Neither showed nephrocalcinosis on plain abdominal radiograph. but the father had a mild symptomless hypertension of $160100 \mathrm{~mm} . \mathrm{Hg}$.

\section{Treatment}

A preliminary study was performed to determine the effect of sodium phitate on urinary calcium excretion. 
TABLE 4

INVESTIGATIONS ON THE PATIENTS FAMILY

\begin{tabular}{|c|c|c|c|c|}
\hline Investigations & & $\begin{array}{l}\text { Father } \\
(43 \text { yr. })\end{array}$ & $\begin{array}{l}\text { Brother } \\
\text { (11 yr.) }\end{array}$ & Mother \\
\hline $\begin{array}{l}\text { Urinary excretion of calcium* } \\
(\mathrm{mg} .24 \mathrm{hr} .)\end{array}$ & . & 517 & $\begin{array}{l}246 \\
256 \\
233 \\
280\end{array}$ & 149 \\
\hline Serum calcium (mg. $100 \mathrm{ml}$ ) & . & $9 \cdot 7$ & $9 \cdot 6$ & \\
\hline $\begin{array}{l}\text { Serum inorganic phosphorus } \\
\text { (mg. } 100 \mathrm{ml} \text {.) } \\
\text { Serum alkaline phosphatase } \\
\text { (King-Armstrong units } 100 \mathrm{ml} \text {.). }\end{array}$ & $\cdots$ & $\begin{array}{l}3 \cdot 1 \\
14\end{array}$ & $\begin{array}{l}4 \cdot 7 \\
17\end{array}$ & \\
\hline Blood urea $(\mathrm{mg} .100 \mathrm{ml}$.) $\ldots$ & .. & 17 & 9 & \\
\hline Straight radiograph of abdomen & .. & Normal & Normal & \\
\hline
\end{tabular}

- Normal value for men: 100-300 mg. daily (Hodgkinson and Pyrah, 1958); normal value for women. 100-250 mg. daily (Hodgkinson and Pyrah, 1958); and normal value for boys 11 years old. $74=17 \mathrm{mg}$. daily (Macy, 1942).

On a constant diet providing $650 \mathrm{mg}$. of calcium daily, sodium phytate was administered in a dosage of $1.8 \mathrm{~g}$. daily and then $3.6 \mathrm{~g}$. daily, divided into four doses, with meals for five-day periods, i.e. sufficient to precipitate 189 and $378 \mathrm{mg}$. calcium respectively. Owing to severe constipation accurate collections of stools were impossible and a proper metabolic balance could not be performed. The calcium excretion in the urine was determined daily,

TABLE $5 \mathrm{a}$ and $\mathrm{b}$

TREATMENT WITH SODIUM PHYTATE a: Preliminary Study

\begin{tabular}{|c|c|c|c|}
\hline $\begin{array}{l}\text { Three } \\
\text { Five-day } \\
\text { Periods }\end{array}$ & $\begin{array}{c}\text { Intake of } \\
\text { Sodium Phytate } \\
\text { (g./day) }\end{array}$ & \multicolumn{2}{|c|}{$\begin{array}{c}\text { Urinary Cakcium } \\
(\mathrm{mg} / 24 \mathrm{hr} .\end{array}$} \\
\hline $\begin{array}{l}a \\
b \\
c \\
d \\
e\end{array}$ & $\begin{array}{l}0 \\
0 \\
0 \\
0 \\
0\end{array}$ & $\left.\begin{array}{l}169 \\
182 \\
195 \\
160 \\
192\end{array}\right)$ & mean $179 \mathrm{mg}$. \\
\hline $\begin{array}{l}\text { f } \\
\text { g } \\
\mathbf{h} \\
\mathbf{i} \\
\mathbf{j}\end{array}$ & $\begin{array}{l}1 \cdot 8 \\
1 \cdot 8 \\
1.8 \\
1.8 \\
1 \cdot 8\end{array}$ & $\left.\begin{array}{l}153 \\
127 \\
145 \\
144 \\
156\end{array}\right)$ & mean $145 \mathrm{mg}$. \\
\hline $\begin{array}{l}\mathbf{k} \\
\mathbf{l} \\
\mathbf{m} \\
\mathbf{n} \\
\mathbf{o}\end{array}$ & $\begin{array}{l}3 \cdot 6 \\
3 \cdot 6 \\
3 \cdot 6 \\
3 \cdot 6 \\
3 \cdot 6\end{array}$ & $\left.\begin{array}{l}150 \\
103 \\
115 \\
109 \\
137\end{array}\right)$ & mean $123 \mathrm{mg}$. \\
\hline
\end{tabular}

b: Calcium balance $V$ five months after beginning therapy with $1.8 \mathrm{~g}$. sodium phytate daily (Fig. 1) (all results in mg.)

\begin{tabular}{|c|c|c|c|c|c|}
\hline Diet for 5 days* . & $\cdots$ & . & $\cdots$ & $\ldots$ & 2,603 \\
\hline $\begin{array}{l}\text { Urinary excretion over } \\
\text { Faecal excretion }{ }^{\dagger} \\
\text { Output over } 5 \text { days }\end{array}$ & $\begin{array}{l}5 \text { days } \\
\ldots \\
\cdots\end{array}$ & $\begin{array}{l}\cdots \\
\cdots \\
\cdots\end{array}$ & $\begin{array}{l}\cdots \\
\cdots \\
\cdots\end{array}$ & $\begin{array}{l} \\
\cdots \\
\cdots\end{array}$ & $\begin{array}{r}730 \\
+1,210 \\
=1,940\end{array}$ \\
\hline Balance per day & . & .. & $\ldots$ & . & +133 \\
\hline
\end{tabular}

- Exact duplicates of food and fluids were provided by the child's mother.

+ Stools were collected between markers 10 days apart because of constipation. The faecal figure is corrected for 5 days. and the results are given in Table 5. A fall in the excretion of calcium in the urine was demonstrated, and the administration of sodium phytate was considered a suitable method of treatment. Initial dosage erred on the cautious side for fear of inducing osteoporosis by leaving too little calcium available for absorption.

The child was discharged on $1.8 \mathrm{~g}$. sodium phytate daily, and his cakcium excretion one and two months later was 117 and $63 \mathrm{mg} . / 24$ hours respectively. After five months he was well and a balance study performed at home (Table 5) showed he was still in positive calcium balance, and that his urinary calcium was still less than before treatment. Eight months after beginning treatment his urinary calcium was $215 \mathrm{mg}$. $/ 24$ hours in one collection, though the child's father stated his son was much improved, very lively and free of attacks of abdominal pain. However, two weeks later he had an attack of pain and a further 24-hour urine contained $246 \mathrm{mg}$. of calcium. His mother was asked to record his food and fluid intake, and his calculated intake of calcium on each of three days was $1,050,841$, and $958 \mathrm{mg}$. Since his calcium intake was so much higher than it had been five months after beginning treatment, and his dose of sodium phytate had remained unchanged, it was considered that he was no longer receiving sufficient phytate to prevent the absorption of excessive amounts of calcium.

The dose of sodium phytate was then increased to $5 \cdot 4 \mathrm{~g}$. daily (sufficient to bind $565 \mathrm{mg}$. calcium) and the calcium excretion in two 24-hour urines two weeks later had fallen to 158 and $88 \mathrm{mg}$. After a further four weeks on this dosage the excretion had risen again to 158 and $213 \mathrm{mg}$. ' 24 hours.

Accordingly the dose was further raised to $9.0 \mathrm{~g}$. daily (sufficient to bind $945 \mathrm{mg}$. calcium). Four weeks later, urinary calcium excretions were 172 and $210 \mathrm{mg}$./24 hours, and eight weeks later 174 and $228 \mathrm{mg}$./24 hours. The estimated intake of calcium during this time was $1 \cdot 28 \mathrm{~g}$. daily.

The level of serum calcium remained within normal limits during the time that sodium phytate was being given.

Since the sodium phytate appeared to have lost its effect, it was stopped. The urinary calcium excretions two and ten weeks later were still raised at 214 and 235 $\mathrm{mg}$./24 hours, and 178 and $226 \mathrm{mg}$./24 hours. These excretions were similar to those found when the child was receiving $9.0 \mathrm{~g}$. sodium phytate daily.

However, six months after stopping the sodium phytate the urinary calcium excretion had risen to $238 \mathrm{mg}$. and $360 \mathrm{mg} . / 24$ hours, and though the patient felt well his increase in height had halted for six months (Fig. 2). These facts suggested that we had been wrong in assuming that sodium phytate had completely lost its effect. Since the return of his hypercalcuria and cessation of growth appeared to be related, a further attempt will be made to reduce his urinary calcium excretion. He will be given oral sodium dihydrogen phosphate (Dent, 1962) to try and diminish any excess parathyroid activity. If this is ineffective he will be given larger doses of sodium phytate. 

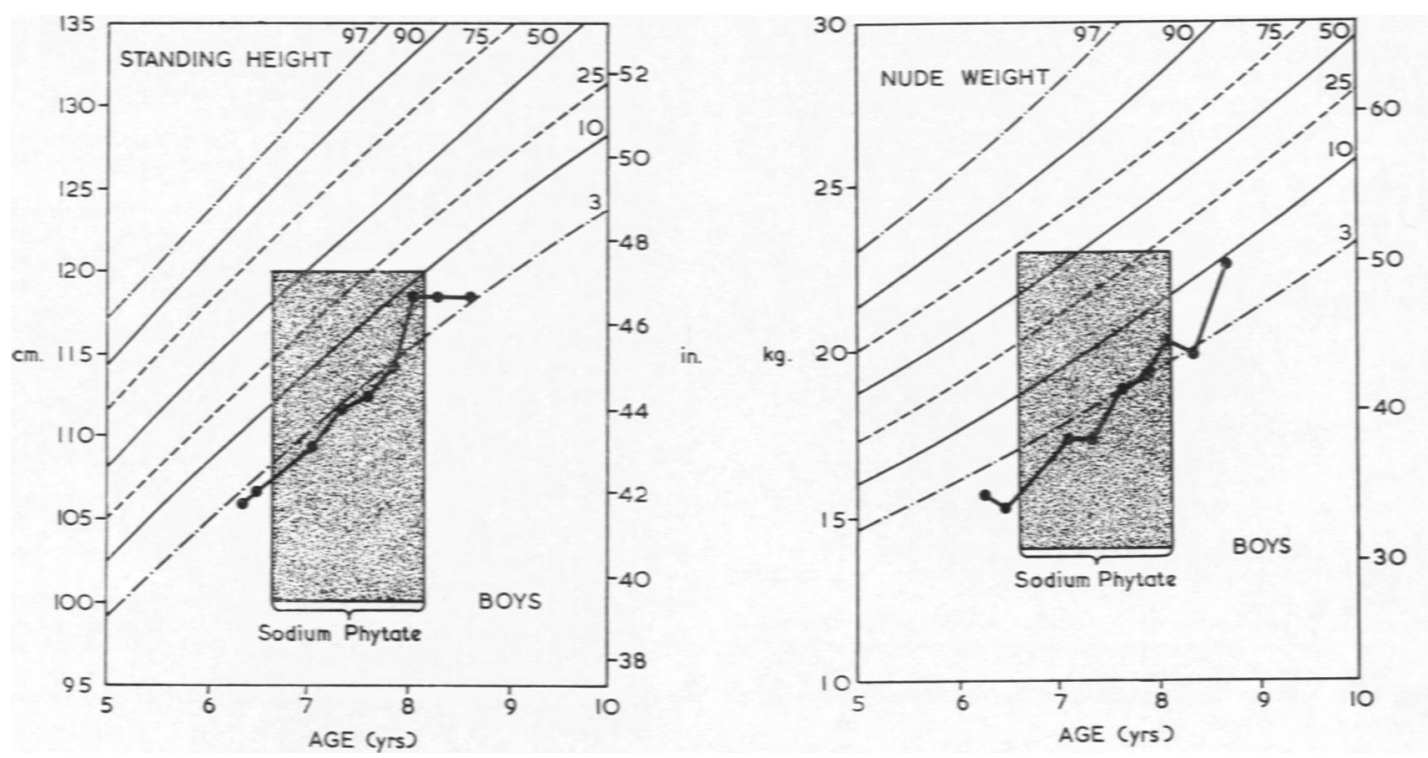

Fig. 2.-Growth charts for E.B.

\section{Discussion}

Idiopathic hypercalcuria with nephrocalcinosis has not been described in a child though it is well documented in adults. Four children (aged 3, 5, 8, and 11 years) with idiopathic hypercalcuria without nephrocalcinosis have been described by Royer (1962) but they were all dwarfed, had retarded bone ages, and impaired renal concentrating power. Their urinary excretions of calcium fell on a low calcium diet, and two of them had gross reduction in calcuria when given hydrochlorothiazide. Their families were not studied.

The presence of nephrocalcinosis and failure to thrive in E.B. but not in his father or brother, who also have hypercalcuria, is difficult to explain. It suggests an additional lesion in E.B.'s kidney, and chronic pyelonephritis seems the most likely. There was no definite history of renal infection unless the vomiting in infancy was due to this.

Mortensen, Emmett, and Baggenstoss (1953) estimated that pyelonephritis accounted for $15 \%$ of cases of nephrocalcinosis, and was only exceeded as a cause by hyperparathyroidism and renal tubular acidosis. He studied patients who had normal renal function for ten years despite extensive nephrocalcinosis; it is not known whether they had hypercalcuria.

Investigations showed that both low calcium diet or sodium phytate would reduce the urinary excretion of calcium. Oral sodium phytate seemed most practicable in this young child for whom a low calcium diet would have been unpleasant. There was always the possibility that in time E.B. would compensate for the reduced calcium absorption due to phytic acid. This was noted by Nicolayson et al. (1953), though these workers emphasized that this was not invariable and differences between individuals with respect to compensation were large. The mechanism of resistance to phytic acid is obscure. There may be some way in which the intestines can overcome the effect of phytic acid on calcium absorption. Alternatively, the effect of sodium phytate may persist but the decreased calcium absorption may lead to increased parathyroid activity which maintains the normal serum calcium and the hypercalcuria. The subsequent rise in E.B.'s urinary calcium and cessation of growth in height after stopping phytic acid suggests that in fact he never completely escaped from the drug's action; it is more probable that the dose was not pushed sufficiently high.

In most patients with a high urinary excretion of calcium no cause is found. It has been suggested that there may be a renal tubular defect in the reabsorption of calcium, or primary excessive intestinal absorption of calcium, or abnormal sensitivity to vitamin D (Albright, Henneman, Benedict and Forbes, 1953; Henneman et al., 1958; Jackson and Dancaster, 1959), but none of these theories fits all the facts. 
We are grateful to Sir Wilfrid Sheldon for allowing us to investigate this patient. We thank Mr. J. Mitchell, A.I.M.L.T., for all his technical assistance with the metabolic studies. We received invaluable help from Mrs. D. Dixon, B.Sc., who provided the diets, Mr. A. Allnutt, B.Pharm., members of the Nursing Staff, and members of the Department of Medical Illustration. We are grateful to the Research Committee of The Hospital for Sick Children for financial assistance with this investigation. The sodium phytate was kindly provided by Mr. S. Alexander of Knorr-Brown \& Polson.

\section{REFERENCES}

Albright, F., Henneman. P.. Benedict, P. H. and Forbes, A. P. (1953). Idiopathic hypercalciuria (A preliminary report). Proc. roy. Soc. Med., 46, 1077.

Clavton, B. E. and Cotton, D. A. (1961). A study of malabsorption after resection of the entire jejunum and the proximal half of the ileum. Gut, 2, 18.

Dent, C. E. (1962). Some problems of hyperparathyroidism. Brit. med. J., 2, 1495.
Henneman, P. H., Benedict, P. H., Forbes. A. P. and Dudley, H. R. (1958). Idiopathic hypercalcuria. New Engl. J. Med., 259, 802.

- Dempsey, E. F., Carroll, E. L. and Albright, F. (1956). The cause of hypercalcuria in sarcoid and its treatment with cortisone and sodium phytate. J. clin. Invest.. 35, 1229.

Hodgkinson, A. and Pyrah, L. N. (1958). The urinary excretion of cakcium and inorganic phosphate in 344 patients with calcium stone of renal origin. Brit. J. Surg., 46, 10.

Hoff-Jergensen, E. (1946). The effect of phytic acid on the absorption of cakcium and phosphorus. 1. In dogs. Biochem. J., 40, 189.

-, Andersen, O., and Nielsen, G. (1946). The effect of phytic acid on the absorption of calcium and phosphorus. 3. In children. ibid., 40, 555.

Jackson, W. P. U. and Dancaster, C. (1959). A consideration of the hypercakiuria in sarcoidosis idiopathic hypercalciuria, and that produced by vitamin D. J. clin. Endocr., 19, 658.

Knapp, E. L. (1947). Factors influencing the urinary excretion of cakium. I. In normal persons. J. clin. Invest., 26, 182.

Macy, I. G. (1942). Nutrition and Chemical Growth in Childhood, Vol. 1. Thomas, Springfield, Illinois.

Mortensen, J. D., Emmett, J. L. and Baggenstoss, A. H. (1953). Clinical aspects of nephrocalcinosis. Proc. Mayo Clin.. 28, 305.

Nicolaysen, R., Eeg-Larsen N. and Malm, O. J. (1953). Physiology of calcium metabolism. Physiol. Rev., 33, 424.

Royer, P. (1962). L'hypercalciurie idiopathique avec nanisme et atteinte rénale chez l'enfant. Maandschr. Kindergeneesk., 30, 423.

Wilkinson, R. H. (1957). A micro-method for serum calcium and serum magnesium. J. clin. Path., 10, 126.

- (1960). Chemical Micromethods in Clinical Medicine. Thomas, Springfield, Illinois. 